\title{
Gene and protein expression in pituitary corticotroph adenomas: a systematic review of the literature
}

\author{
Justin Seltzer, BA, ${ }^{2}$ Charles E. Ashton, MS, ${ }^{1}$ Thomas C. Scotton, BS, ${ }^{2}$ Dhiraj Pangal, ${ }^{1}$ \\ John D. Carmichael, MD, ${ }^{3}$ and Gabriel Zada, MD ${ }^{1,2}$
}

1Zilka Neurogenetics Institute, ${ }^{2}$ Department of Neurosurgery, and ${ }^{3}$ Division of Endocrinology, Department of Medicine, Keck School of Medicine of USC, Los Angeles, California

OBJECT Functional corticotroph pituitary adenomas (PAs) secrete adrenocorticotropic hormone (ACTH) and are the cause of Cushing's disease, which accounts for $70 \%$ of all cases of Cushing's syndrome. Current classification systems for PAs rely primarily on laboratory hormone findings, tumor size and morphology, invasiveness, and immunohistochemical findings. Likewise, drug development for functional ACTH-secreting PAs (ACTH-PAs) is limited and has focused largely on blocking the production or downstream effects of excess cortisol. The authors aimed to summarize the findings from previous studies that explored gene and protein expression of ACTH-PAs to prioritize potential genetic and protein targets for improved molecular diagnosis and treatment of Cushing's disease.

METHODS A systematic literature review was performed using the Preferred Reporting Items for Systematic Reviews and Meta-Analyses (PRISMA) guidelines. A PubMed search of select medical subject heading (MeSH) terms was performed to identify all studies that reported gene- and protein-expression findings in ACTH-PAs from January 1, 1990, to August 24, 2014, the day the search was performed. The inclusion criteria were studies on functional ACTH-PAs compared with normal pituitary glands, on human PA tissue only, with any method of analysis, and published in the English language. Studies using anything other than resected PA tissue, those that compared other adenoma types, those without baseline expression data, or those in which any pretreatment was delivered before analysis were excluded.

RESULTS The primary search returned 1371 abstracts, of which 307 were found to be relevant. Of those, 178 were selected for secondary full-text analysis. Of these, 64 articles met the inclusion criteria and an additional 4 studies were identified from outside the search for a total of 68 included studies. Compared with the normal pituitary gland, significant gene overexpression in 43 genes and 22 proteins was reported, and gene underexpression in 58 genes and 15 proteins was reported. Immunohistochemistry was used in 39 of the studies, and reverse transcriptase polymerase chain reaction was used in 26 of the studies, primarily, and as validation for 4 others. Thirteen studies used both immunohistochemistry and reverse transcriptase polymerase chain reaction. Other methods used included microarray, in situ hybridization, Northern blot analysis, and Western blot analysis. Expression of prioritized genes emphasized in multiple studies were often validated on both the gene and protein levels. Genes/proteins found to be overexpressed in ACTH-PAs relative to the normal pituitary gland included $h P T T G 1 /$ securin, NEUROD1/NeuroD1 (Beta2), HSD11B2/11ß-hydroxysteroid dehydrogenase 2, AKTIAkt, protein kinase B, and CCND1/cyclin D1. Candidate genes/proteins found to be underexpressed in ACTH-PAs relative to the normal pituitary gland included CDKN1B/p27 Kip1, CDKN2A/p16, KISS1/kisspeptin, ACTHR/ ACTH-R, and miR-493.

CONCLUSIONS On the basis of the authors' systematic review, many significant gene and protein targets that may contribute to tumorigenesis, invasion, and hormone production/secretion of ACTH have been identified and validated in ACTH-PAs. Many of these potential targets have not been fully analyzed for their therapeutic and diagnostic potential but may represent candidate molecular targets for biomarker development and drug targeting. This review may help catalyze additional research efforts using modern profiling and sequencing techniques and alteration of gene expression.

http://thejns.org/doi/abs/10.3171/2014.10.FOCUS14683

KEY WORDS gene expression; protein expression; corticotroph; ACTH; pituitary adenoma

\footnotetext{
ABBREVIATIONS ACTH = adrenocorticotropic hormone; CDK = cyclin-dependent kinase; IHC = immunohistochemistry; MeSH = medical subject heading; miRNA = microRNA; mTOR = mammalian target of rapamycin; PA = pituitary adenoma; POMC = proopiomelanocortin; PRISMA = Preferred Reporting Items for Systematic Reviews and Meta-Analyses; PTEN = phosphatase and tensin homolog; RT-PCR = reverse transcriptase polymerase chain reaction; VEGF = vascular epithelial growth factor. SUBMITTED September 30, 2014. ACCEPTED October 28, 2014 INCLUDE WHEN CITING DOI: 10.3171/2014.10.FOCUS14683.

DISCLOSURE Dr. Carmichael has served as a consultant for Corcept Therapeutics, Inc., and Novartis and has received non-study-related clinical or research support from Novartis; the other authors report no conflict of interest concerning the materials or methods used in this study or the findings specified in this paper.
} 
$\mathrm{P}$ ITUITARY adenomas (PAs) are common tumors with an overall prevalence in the general US population estimated at $16.7 \% .{ }^{19}$ Corticotroph adenomas, comprising functional and silent corticotroph adenomas, represent approximately $10 \%-15 \%$ of all PAs. ${ }^{4}$ Functional adrenocorticotropic hormone-secreting PAs (ACTH-PAs) secrete inappropriate amounts of ACTH, which results in disorderly and excessive production of cortisol by the adrenal gland. ${ }^{3}$ Functional ACTH-PAs (Cushing's disease) are the most common cause of Cushing's syndrome (hypercortisolemia from any source) and account for an estimated $70 \%$ of all cases. ${ }^{59}$ The prevalence of Cushing's disease is estimated to be 39 per 1,000,000 people ${ }^{20}$ (approximately 12,000 people affected in the United States alone). This number, however, may be much higher, given that Cushing's disease is frequently misdiagnosed and the diagnosis is often delayed. ${ }^{58}$

Current classification systems for PAs are based primarily on secretory characteristics of the tumor but are also classified on the basis of phenotypical characteristics, including tumor size, degree of invasiveness (e.g., Knosp scoring system), and immunohistological findings. ${ }^{36}$ The WHO classification system for PAs has been refined to include designations for benign adenoma, atypical adenoma, and pituitary carcinoma on the basis of p53 immunoreactivity, MIB-1 index, mitotic activity, and the absence/presence of metastases. ${ }^{7,105}$ More comprehensive molecular classification systems based on relevant gene expression have not been systematically used to further characterize pituitary tumors.

Transsphenoidal resection remains the first-line treatment for most patients with Cushing's disease. Radiosurgery, radiation therapy, medical therapy, and bilateral adrenalectomy are second-line treatments often implemented or reserved as adjuvant treatments for patients with refractory Cushing's disease. . $^{15} 61$

Currently available pharmacological agents for treating functional ACTH-PAs include ketoconazole, mifepristone, and pasireotide. Ketoconazole, which blocks steroid hormone production, is the primary drug used for this purpose despite it not being formally approved for this use. It is nonspecific and can cause significant reduction of androgen levels and hepatic dysfunction. Pasireotide is a novel somatostatin receptor ligand with greater affinity for the SSTR5 receptor. SSTR5 receptors have been found in high density in functional ACTH-PAs, and treatment with this agent reduces abnormal ACTH secretion and reduces tumor volume. Adverse effects include an increased risk of developing or worsening diabetes mellitus and the adverse gastrointestinal effects commonly seen with this class of drug. ${ }^{13}$ Mifepristone, a progesterone receptor antagonist with potent glucocorticoid receptor antagonist activity, effectively blocks cortisol activity at the level of the receptor, improving morbidities associated with Cushing's syndrome. Common adverse effects include hypokalemia, vaginal bleeding, and symptoms of adrenal steroid withdrawal. ${ }^{23}$

In the near future, personalized molecular strategies are likely to improve diagnosis and therapeutics in patients with ACTH-PAs. To summarize and consolidate findings pertaining to ACTH-PAs and prioritize targets for further drug development and molecular classification systems for patients with Cushing's disease, we reviewed the literature to identify gene- and protein-expression findings in ACTH-PAs. In this article, we present the results of a systematic literature review conducted to identify overexpression and underexpression of genes and proteins that are associated with the development, invasion, and hormonal secretion of ACTH-PAs. By collecting, analyzing, and presenting this information, we hope to shed additional light on prioritized genes and molecular mechanisms associated with specific phenotypical outcomes, potential therapeutic targets, and promising areas of further research.

\section{Methods}

\section{Overview of Systematic Literature Review}

A systematic literature review was performed to identify all published reports that detailed gene-expression changes and proteins in functional ACTH-PAs relative to the normal pituitary gland.

\section{Preliminary Search Strategy and Terms}

The primary objective of the search strategy was to identify all contemporary published studies pertaining to gene expression in functional ACTH-PAs. A detailed systematic search strategy was created by informally searching relevant articles and capturing the most common medical subject heading $(\mathrm{MeSH})$ terms. MeSH terms and Boolean functions were used instead of simpler search strings as a means of creating a more focused search along varied criteria. To focus on results from more modern techniques, all search results were limited to those published between January 1, 1990, and August 24, 2014, but no other limitations were initially placed on the data collection.

The search of contemporary articles was performed according to the Preferred Reporting Items for Systematic Reviews and Meta-Analyses (PRISMA) guidelines. ${ }^{54}$ Using the PubMed database, our search involved a string of the following MeSH terms: ((pituitary neoplasms/genetics[MeSH terms]) OR (pituitary neoplasms/ pathology[MeSH terms]) OR (pituitary neoplasms/ metabolism[MeSH terms]) OR (pituitary neoplasms/ chemistry[MeSH terms])) AND (humans[MeSH terms]) AND ((immunohistochemistry[MeSH terms]) OR (reverse transcriptase polymerase chain reaction[MeSH terms]) $O R$ (gene expression regulation, neoplastic[MeSH terms]) $O R$ (gene expression profiling[MeSH terms]) OR (oligonucleotide array sequence analysis[MeSH terms]) OR (microarray analysis[MeSH terms]) OR (gene expression[MeSH terms])).

\section{Inclusion and Exclusion Criteria}

Inclusion criteria were the following: 1) functional ACTH-PAs compared with the normal pituitary gland; 2) analyses of human tissue only; 3) any method of measuring and analyzing protein and/or mRNA expression; and 4) studies published in the English language.

Articles were excluded on the basis of the following: 1) use of anything but resected human PA tissue, including primary cultures, cell lines, or transfected cells; 2) 
gene-expression comparisons between various PA tumor types or between adenomas and carcinomas; 3) expression or no expression validation without any baseline; or 4) any defined medical pretreatment of the tumor before analysis.

\section{Implementation of the Search Strategy and Study Selection Process}

A preliminary review of the search results was conducted. All the articles were initially screened by 1 reviewer (J.S.) for relevancy on the basis of their titles and abstracts. Any report not excluded by this process was included for full-text analysis. The reports were then subjected to fulltext analysis using our inclusion and exclusion criteria. The articles were reviewed by 2 readers independently (J.S. and D.P.); in total, 5 articles differed between the 2 analyses and were reconciled by joint review.

\section{Data Collection Process}

From the included studies, information of interest primarily concerned gene and/or protein expression and experimental methods and results. The primary outcomes recorded were tumor type(s) analyzed, expression analysis type(s), results of expression analysis, and any relevant commentary (e.g., association with invasiveness).

\section{Potential for Bias}

The search and subsequent analyses were intended to be as unbiased as possible. The preliminary search was performed solely on the basis of relevance and time period (after 1990) with no consideration given to the source, author, institution, or other unique identifying criterion. The primary screening process was performed by one author and subsequently reviewed by another author, which potentially introduced a source of bias.

All full-text studies were reviewed independently by 2 readers only on the basis of our inclusion and exclusion criteria. Furthermore, these inclusion and exclusion criteria were defined before beginning the screening process. Discrepancies between the reviewers were resolved using the inclusion and exclusion criteria. Finally, we had no competing interests and received no outside funding from any source for this research.

\section{Quality Assessment}

A formal quality assessment was not performed. However, each full-text article we reviewed included an informal review of the materials, methods, and results. Although this was done primarily to satisfy the inclusion and exclusion criteria, it also enabled us to assess the quality of the studies. No studies were excluded on the basis of poor-quality methods or results.

\section{Results}

\section{Literature Review}

The search yielded 1371 initial results, of which 307 articles were selected for review on the basis of the relevancy of their titles and abstracts. Of the 307 studies that were reviewed primarily, 178 were selected for full-text analysis. After an in-depth review of 178 full reports, 60 were selected for inclusion on the basis of our inclusion and exclusion criteria. Four articles were added to the review from outside of the formal literature review, sourced from the informal search that yielded the MeSH terms detailed earlier. These reports were subjected to and passed the same inclusion and exclusion criteria as those the search generated. After combining both groups, a total of 64 articles were analyzed. A PRISMA diagram detailing the search results is shown in Fig. 1.

In total, 43 genes and 22 proteins were identified as being overexpressed and 58 genes and 15 proteins as underexpressed in functional ACTH-PAs compared with those in normal pituitary gland tissue. Many of the genes were also characterized by immunostaining for the resulting gene product/protein, all of which paralleled the levels of gene expression. The provided protein data refer only to proteins identified via immunohistochemistry (IHC) and/ or Western blotting without analysis of the underlying gene expression.

Of the genes, NEURODl and hPTTGl were overexpressed in 3 different studies, whereas $H I G D I B$ and $H S D 11 B 2$ were overexpressed in 2 studies. Underexpression of $C D K N 1 B, C D K N 2 A$, and let-7 was shown in 4, 2, and 2 studies, respectively. Concerning the proteins, only c-myc was shown by IHC analysis to be overexpressed in more than 1 study. Underexpression of 2 proteins was shown multiple times: p27 ${ }^{\mathrm{Kip} 1}$ in 4 studies (all by IHC) and p16 in 2 studies ( 1 by Western blot analysis and 1 by IHC).

The most common method of analysis was IHC, which was used as the primary method in 39 studies. The second most common was reverse transcriptase polymerase chain reaction (RT-PCR), which was used as the primary method in 26 studies and as a validation method in 4 others in which microarray was used as the primary method. It should be noted that 13 studies used RT-PCR and IHC together. Microarray analysis was used in 6 studies, in situ hybridization in 5, Northern blot analysis in 4, and Western blot analysis in 3. Table 1 details their full results.

\section{Analysis \\ Analytical Focus}

The following discussion highlights some of the genes and proteins from articles included in the systematic review. Given that the exhaustive list of genes and proteins (Table 1) we obtained was too large to fully discuss in this review, a selective analytical approach was used to prioritize this discussion of genes. The genes and gene products selected for further discussion were based on articles that demonstrated both gene- and protein-expression differences. Although any type of method was permitted, these findings were most frequently obtained by using RTPCR and IHC staining. Further consideration was given to genes and proteins that were recurring findings in multiple studies. Also included were microRNAs (miRNAs), important emerging elements of gene and protein expression that are analyzed primarily by microarray and confirmed by using RT-PCR. See Table 2 for a summary of highlighted genes and proteins. 

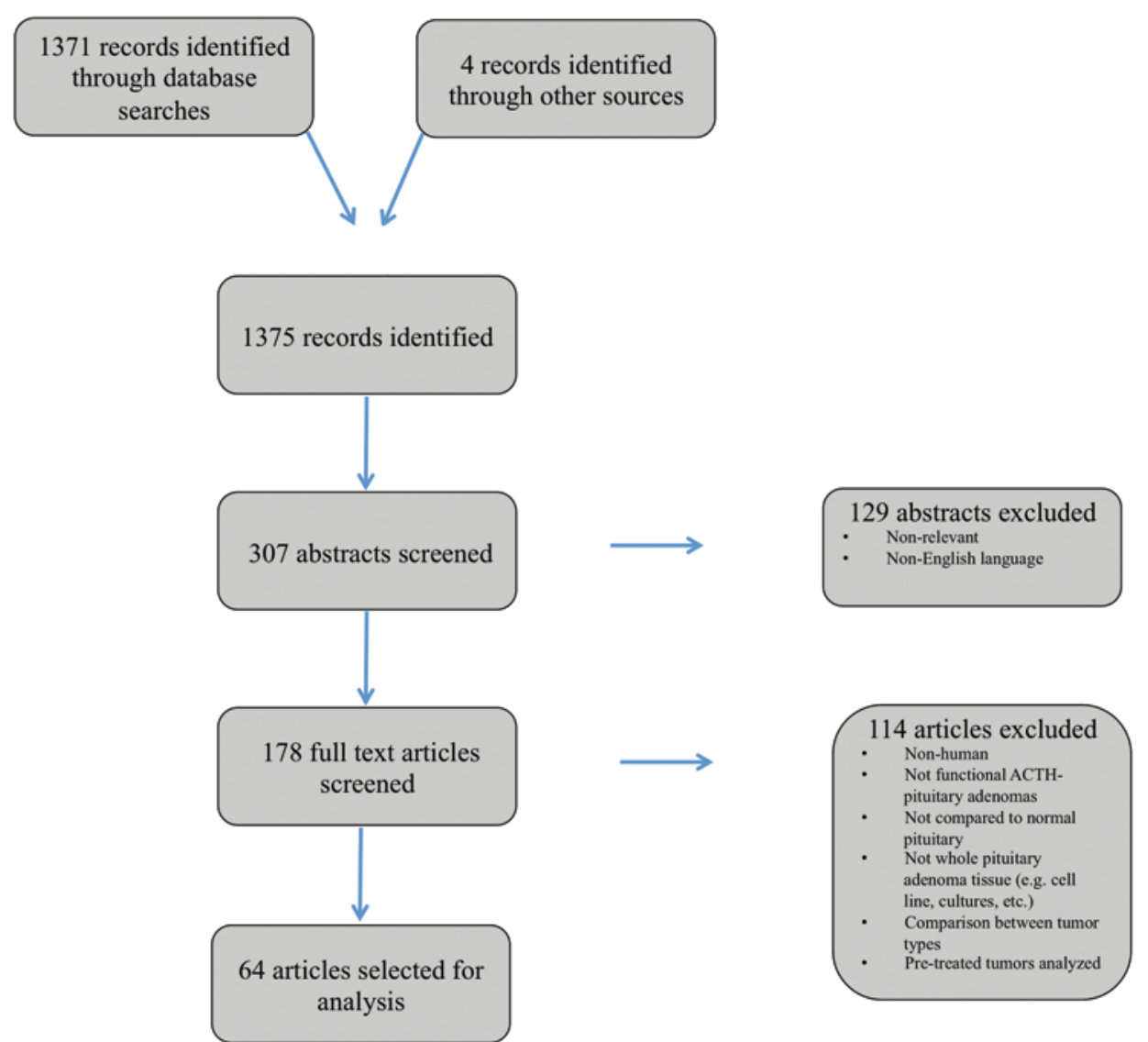

FIG. 1. PRISMA diagram detailing the specifics of the systematic literature review.

\section{Overexpressed Genes in ACTH-PAs hPTTG1/Securin}

Pituitary tumor-transforming gene, or PTTG, was first isolated in the GH4 rat pituitary tumor cell line in 1997 by Pei and Melmed. ${ }^{64}$ Their discovery was based on both differential gene expression and comparison of quantitative mRNA analysis from normal and adenomatous pituitary cells. It was validated by implantation of transfected 3T3 cells into mice, which resulted in tumor formation after 3 weeks.

The human variant, hPTTGl, was localized and characterized by Zhang et al. ${ }^{108}$ and was found to be expressed in normal adult human testis, thymus, colon, small intestine, brain, and lung and in fetal liver. An analysis of PA and various nonpituitary and pituitary carcinoma tissues showed increased hPTTGl expression in adenomas and even greater expression in carcinomas. Sáez et al. ${ }^{76}$ confirmed these findings. From this analysis, hPTTGl was classified as an proto-oncogene. As an important aside, some articles used hPTTGI and PTTG interchangeably; we used whichever name was described in the article.

Additional studies determined the more specific role of hPTTGl in PA development. In 1999, Zhang et al. ${ }^{107}$ showed that increased hPTTGl expression was associated with invasiveness in functional PAs. In 2001, Pei ${ }^{63}$ showed that $c-M y c$ is a downstream target of PTTG, and Woloschak et al. ${ }^{101}$ and Wang et al. ${ }^{95}$ previously determined by IHC that c-myc was overexpressed in functional ACTHPAs. Given that $c-M y c$ is also a known oncogene ${ }^{97}$ the role of $h P T T G l$ in its activation is an important connection. Jallepalli et al..$^{30}$ showed in 2001 that securin, the protein encoded by $h P T T G l$, is involved in maintaining chromosomal stability during cell division. Furthermore, in 2006, Minematsu et al..$^{53}$ showed that the expressions of $h P T T G 1$ and vascular epithelial growth factor (VEGF) were correlated in PAs. In the same year, Filippella et al. ${ }^{22}$ showed a correlation between $h P T T G 1$ expression and the Ki-67 nuclear proliferation index, linking $h P T T G l$ expression to PA aggressiveness, invasiveness, and recurrence potential. Recent studies more fully elucidated these mechanisms in both pituitary and nonpituitary tissues, representing an active area of research. With the data taken as a whole, the overexpression of $h P T T G 1$ has a well-supported and wellrecognized multifaceted role in PA tumorigenesis.

\section{NEUROD1/NeuroD1 (Beta2)}

NEURODI is a gene that codes for NeuroD1, also known as Beta2, a basic helix-loop-helix transcription factor involved in tissue determination and differentiation, particularly for neurogenesis ${ }^{75}$ and the activation of various adult genes (e.g., insulin). ${ }^{48}$ In 1997, Poulin et al.$^{65}$ also showed that NeuroD1 is expressed in normal corticotroph cells in the pituitary gland to promote the transcription of proopiomelanocortin (POMC). POMC is the main precur- 
TABLE 1. Results of systematic literature review

\begin{tabular}{|c|c|c|c|c|}
\hline Authors \& Year & Upregulated Genes/Proteins & Downregulated Genes/Proteins & Tumor Type & Analysis Type \\
\hline Alberti et al., 1991 & IGF-1 & None & ACTH & $\mathrm{IHC}$ \\
\hline Amaral et al., 2009 & None & $\begin{array}{l}\text { let-7a, miR-15a, miR-16, miR-21, miR-141, } \\
\text { miR-143, miR-145, miR-150 }\end{array}$ & ACTH & RT-PCR \\
\hline $\begin{array}{l}\text { Assimakopoulou et al., } \\
2008\end{array}$ & None & p75(NTR) & $\begin{array}{l}\text { NF, GH, GH/PRL, } \\
\text { ACTH }\end{array}$ & $\mathrm{IHC}$ \\
\hline Bamberger et al., 1999 & None & p27 Kip1 (CDKN1B) & General & $\mathrm{IHC}$ \\
\hline \multirow[t]{2}{*}{ Bottoni et al., 2007} & $\begin{array}{l}\text { miR-212, miR-026a, miR-150, } \\
\text { miR-152, miR-191, miR- } \\
\quad 192\end{array}$ & miR-024-1, miR-098 & General & Microarray \\
\hline & $\begin{array}{l}\text { miR-30a, miR-30b, miR-30c, } \\
\quad \text { miR-30d }\end{array}$ & miR-23a, miR- 23b, miR-24-2 & ACTH & \\
\hline Buslei et al., 2006 & None & SOCS1 (SOCS1 protein) & General & $\begin{array}{l}\text { RT-PCR, Western } \\
\text { blotting }\end{array}$ \\
\hline Chile et al., 2011 & RERG & None & ACTH & Microarray \\
\hline Cornelius et al., 2012 & ESM1 (Endocan protein) & None & ACTH, NF, GH & RT-PCR, IHC \\
\hline de Keyzer et al., 1998 & V3, POMC, CRH-R & None & ACTH & RT-PCR \\
\hline Dieterich \& Lehnert, 2000 & None & CRFBP & ACTH & RT-PCR \\
\hline Elston et al., 2008 & None & $\begin{array}{l}\text { WIF1 (WIF1 protein), SFRP2 (SFRP2 } \\
\text { protein), SFRP4 (SFRP4 protein) }\end{array}$ & General & $\begin{array}{l}\text { Microarray, RT-PCR, } \\
\text { IHC, DNA meth- } \\
\text { ylation sequenc- } \\
\text { ing }\end{array}$ \\
\hline Evans et al., 2001 & CMP-tk (MERTK) & $O D C$ & ACTH & RT-PCR (microarray) \\
\hline Ferretti et al., 2003 & $\begin{array}{l}\text { NEUROD1 (NeuroD1/Beta2 } \\
\text { protein) }\end{array}$ & None & ACTH, NF & $\begin{array}{l}\text { RT-PCR, Northern } \\
\text { blotting, IHC }\end{array}$ \\
\hline \multirow[t]{2}{*}{ Fratticci et al., 2007} & NGN2 (Neurog2 protein) & None & $\begin{array}{l}\text { GH, PRL, ACTH, } \\
\text { TSH, NF }\end{array}$ & RT-PCR, IHC \\
\hline & NeuroD1 & None & NF, TSH, ACTH & \\
\hline Giorgi et al., 2008 & NTR3 (NT protein) & None & $\mathrm{GH}, \mathrm{PRL}, \mathrm{ACTH}, \mathrm{NF}$ & RT-PCR, IHC \\
\hline Hashimoto et al., 1994 & None & PC2 & ACTH & Northern blotting \\
\hline Hewedi et al., 2011 & Cyclin D1 & None & General & $\mathrm{IHC}$ \\
\hline Hossain et al., 2009 & None & CDKN2C (p18 $\left.{ }^{\mid N K 4 C}\right)$ & ACTH, NF, GH, PRL & $\begin{array}{l}\text { IHC, RT-PCR, meth- } \\
\text { ylation analysis }\end{array}$ \\
\hline Hsu et al., 1991 & GAL (Galanin protein) & None & ACTH & $\mathrm{IHC}, \mathrm{ISH}$ \\
\hline Jiang et al., 2010 & $\begin{array}{l}\text { LOC399947, HIGD1B, } \\
\text { CCL3J1, EST, EPS8, } \\
\text { MAD2L1 }\end{array}$ & $\begin{array}{l}\text { HLA-A29.1, CGB5, LHB, CGB1, GNG8, } \\
\text { DAPK2, IGFBP3, 15-PGDH, ITGA2, } \\
\text { ITGB4, LAMA1, COL4A6, TGFB pathway } \\
\text { (THBS2, THBS4, CHRD, ID3, INHBE, } \\
\text { CDKN2B, ID1, SMAD3, SMAD6) }\end{array}$ & ACTH & RT-PCR \\
\hline \multirow[t]{2}{*}{ Jiang et al., 2011} & HIGD1B & $\begin{array}{l}\text { ART3, CGB1, GNRHR, LKL11, LHB, } \\
\text { LOC645781, MGC16121, TDO2, } \\
\text { UGT2B7, VSTM1 }\end{array}$ & General & RT-PCR (microarray) \\
\hline & EPS8, HIGD1B, MAD2L1 & CDKN2B & ACTH & \\
\hline Komatsubara et al., 2001 & None & p27 Kip1 (CDKN1B) & ACTH & $\mathrm{IHC}$ \\
\hline Korbonits et al., 1998 & GHSR & None & ACTH, GH & RT-PCR \\
\hline Korbonits et al., 2001 & HSD11B2 (11ß-HSD2 protein) & None & ACTH & RT-PCR, IHC \\
\hline Lange et al., 1994 & ET1 (ET1 protein) & None & ACTH, GH, NF, PRL & IHC, RT-PCR \\
\hline Lidhar et al., 1999 & None & p27 Kip1 (CDKN1B) & ACTH & $\mathrm{IHC}$ \\
\hline $\begin{array}{l}\text { Martínez-Fuentes et al., } \\
\quad 2011\end{array}$ & None & $\begin{array}{l}\text { KISS1 (kisspeptin protein), KISS1R (kiss- } \\
\text { peptin receptor protein) }\end{array}$ & $\begin{array}{l}\text { ACTH, NF, GH, PRL, } \\
\text { TSH }\end{array}$ & RT-PCR, IHC \\
\hline McCabe et al., 1999 & MEN1 & None & $\mathrm{NF}, \mathrm{GH}, \mathrm{TSH}, \mathrm{ACTH}$ & RT-PCR \\
\hline McCabe et al., 2003 & PTTG, PBF, FGF2, FGF-R-1 & None & General & RT-PCR \\
\hline
\end{tabular}


TABLE 1. Results of systematic literature review (continued)

\begin{tabular}{|c|c|c|c|c|}
\hline Authors \& Year & Upregulated Genes/Proteins & Downregulated Genes/Proteins & Tumor Type & Analysis Type \\
\hline Minematsu et al., 2006 & $\begin{array}{l}\text { hPTTG1 (securin protein), } \\
\text { VEGF (VEGF protein) }\end{array}$ & None & General (except TSH) & RT-PCR, IHC \\
\hline Morris et al., 2003 & None & ACTHR (ACTH receptor protein) & ACTH & RT-PCR, ISH, IHC \\
\hline Musat et al., 2005 & AKT1 (Akt1), AKT2 (Akt2) & CDKN1B (p27 $\left.{ }^{\mathrm{Kip} 1}\right)$, PTEN (PTEN) & ACTH, GH, NF, PRL & RT-PCR, IHC \\
\hline Oyama et al., 2001 & $\begin{array}{l}\text { NEUROD1 (NeuroD1/Beta2 } \\
\text { protein) }\end{array}$ & None & $\mathrm{ACTH}, \mathrm{NF}$ & RT-PCR, IHC \\
\hline Qian et al., 2004 & FGFR4 & None & $\begin{array}{l}\mathrm{GH}, \mathrm{ACTH}, \mathrm{FSH} / \mathrm{LH}, \\
\quad \mathrm{NF}\end{array}$ & $\mathrm{IHC}$, Western blotting \\
\hline Qian et al., 2007 & None & $\begin{array}{l}\mathrm{CDH13} \text { (H-cadherin protein), } \mathrm{CDH} 1 \mathrm{E}- \\
\quad \text { cadherin protein) }\end{array}$ & General & RT-PCR, IHC \\
\hline Qian et al., 2009 & HMGA2 & Let-7 & $\begin{array}{l}\text { PRL, ACTH, FSH/ } \\
\text { LH, NF }\end{array}$ & $\mathrm{IHC}$ \\
\hline Rabbitt et al., 2003 & HSD11B2 & None & General & RT-PCR \\
\hline Raica et al., 2010 & None & EG-VEGF & $\begin{array}{l}\mathrm{GH}, \mathrm{PRL}, \mathrm{ACTH}, \mathrm{NF}, \\
\text { plurihormone }\end{array}$ & $\mathrm{IHC}$ \\
\hline Revill et al., 2009 & None & NNAT (neuronatin protein) & $\mathrm{GH}, \mathrm{PRL}, \mathrm{ACTH}, \mathrm{NF}$ & RT-PCR, IHC \\
\hline Righi et al., 2010 & None & IMP3 (IMP3 protein) & $\begin{array}{l}\text { ACTH, NF, FSH/LH, } \\
\text { GH }\end{array}$ & $\begin{array}{l}\text { IHC, RT-PCR, West- } \\
\quad \text { ern blotting }\end{array}$ \\
\hline Riss et al., 2003 & LGALS3 (Galectin-3 protein) & None & PRL, ACTH & IHC, Western blotting \\
\hline Sáez et al., 1999 & hPTTG1 & None & General & Northern blotting \\
\hline Salehi et al., 2012 & None & MGMT & ACTH & $\mathrm{IHC}$ \\
\hline Seemann et al., 2001 & None & CDKN2A (p16 protein) & $\begin{array}{l}\text { ACTH, GH, NF, pluri- } \\
\text { hormone }\end{array}$ & IHC, RT-PCR \\
\hline Stefaneanu et al., 1991 & POMC & None & ACTH & $\mathrm{IHC}, \mathrm{ISH}$ \\
\hline Stilling et al., 2010 & None & $m i R-493$ & $\begin{array}{l}\text { ACTH, PRL, GH, } \\
\text { FSH/LH, NF }\end{array}$ & RT-PCR (microarray) \\
\hline Tagliati et al., 2010 & Magmas (Tim16) & None & ACTH & $\begin{array}{l}\text { RT-PCR, Northern } \\
\text { blotting }\end{array}$ \\
\hline $\begin{array}{l}\text { Tampanaru-Sarmesiu et } \\
\text { al., } 1998\end{array}$ & Tf (transferrin protein) & None & $\begin{array}{l}\text { GH, PRL, ACTH, TSH, } \\
\quad \text { NF }\end{array}$ & $\mathrm{IHC}, \mathrm{ISH}$ \\
\hline Tannahill et al., 2002 & $D 3, D 1$ & D2 & ACTH & RT-PCR \\
\hline $\begin{array}{l}\text { Theodoropoulou et al., } \\
2004\end{array}$ & None & MEN-1 & $\mathrm{ACTH}, \mathrm{GH}, \mathrm{NF}, \mathrm{PRL}$ & $\mathrm{IHC}$ \\
\hline Turner et al., 2000 & Cyclin A, B, D, \& E & None & ACTH, GH, PRL, NF & $\mathrm{IHC}$ \\
\hline Umeoka et al., 2001 & RCAS-1 & None & $\mathrm{GH}, \mathrm{TSH}, \mathrm{NF}, \mathrm{ACTH}$ & $\mathrm{IHC}$ \\
\hline Velkeniers et al., 1994 & IL6 (Interleukin 6 protein) & None & ACTH, GH & $\mathrm{IHC}, \mathrm{ISH}$ \\
\hline Vidal et al., 2003 & $\operatorname{cox} 2$ & None & General & $\mathrm{IHC}$ \\
\hline Wang et al., 1996 & bcl2, c-myc & None & ACTH, PRL, GH & $\mathrm{IHC}$ \\
\hline Wang et al., 2010 & HMGA1 & None & $\begin{array}{l}\mathrm{NF}, \mathrm{GH}, \mathrm{GH} / \mathrm{PRL} \\
\mathrm{TSH}, \mathrm{ACTH}\end{array}$ & $\mathrm{IHC}$ \\
\hline Wasko et al., 2005 & Survivin & None & General & RT-PCR \\
\hline $\begin{array}{l}\text { Winczyk \& Pawlikowski, } \\
2005\end{array}$ & PPAR-Y & None & General & $\mathrm{IHC}$ \\
\hline Woloschak et al., 1994 & c-myc & None & General & $\mathrm{IHC}$ \\
\hline Woloschak et al., 1996 & None & p16 (CDKN2A) & General & Western blotting \\
\hline Xu et al., 2000 & $\mathrm{CRH}$ & None & ACTH & $\mathrm{ISH}$ \\
\hline Yuan et al., 2008 & None & GSTP1 (associated with invasiveness) & $\mathrm{GH}, \mathrm{PRL}, \mathrm{ACTH}$ & $\mathrm{IHC}$ \\
\hline Zafar et al., 1995 & None & $E R$ (estrogen receptor protein) & ACTH, GH & RT-PCR, IHC \\
\hline Zhang et al., 1999107 & PTTG & None & NF, GH, PRL, ACTH & RT-PCR \\
\hline
\end{tabular}

EG-VEGF = endocrine gland-derived vascular endothelial growth factor; $\mathrm{FSH}$ = follicle-stimulating hormone; $\mathrm{GH}$ = growth hormone; IGF-1 = insulin-like growth factor-1; ISH = in situ hybridization; $\mathrm{LH}$ = luteinizing hormone; NF = nuclear factor; $\mathrm{PRL}$ = prolactin; $\mathrm{TSH}$ = thyroid-stimulating hormone. 
TABLE 2. Summary of highlighted genes and proteins

\begin{tabular}{ll}
\hline Overexpressed Genes/Proteins & Underexpressed Genes/Proteins \\
\hline hPTTG1/securin & CDKN1B/p27 Kip1 \\
\hline NEUROD1/NeuroD1 (Beta2) & CDKN2A/p16 \\
\hline $\begin{array}{l}\text { HSD11B2/11ß-hydroxysteroid de- } \\
\text { hydrogenase 2 }\end{array}$ & KISS1/kisspeptin \\
\hline AKT/Akt, protein kinase B (PKB) & ACTHR/ACTH-R \\
\hline CCND1/cyclin D1 & miR-493 \\
\hline
\end{tabular}

sor molecule for ACTH, which is overproduced by functional ACTH-PAs.

In 2001, Oyama et al..$^{62}$ showed that ACTH-PAs overexpress NEURODI and its protein product. Fratticci et al. ${ }^{24}$ confirmed this result in 2007. This mechanism, however, is not unique to functional ACTH-PAs; it has been shown that NEURODI expression levels are similar among ACTH-secreting tumors of both pituitary and nonpituitary origin.$^{86}$ This finding supports the idea that overexpression of NEURODI and its protein product are associated with a significant independent mechanism involved with ACTH overproduction. The role of NEURODI in PAs, however, has been the focus of limited research and might represent a meaningful future avenue of exploration.

\section{HSD11B2/11 $\beta$-Hydroxysteroid Dehydrogenase 2}

$H S D 11 B 2$ is the gene that codes for the enzyme $11 \beta$ hydroxysteroid dehydrogenase 2 . This enzyme is primarily responsible for oxidizing cortisol into cortisone, which prevents inappropriate saturation of the mineralocorticoid receptors by cortisol, thereby resulting in pseudohyperaldosteronism..$^{98}$ Mutations in this enzyme can result in familial syndromes of apparent mineralocorticoid excess. ${ }^{99}$

In 2001, Korbonits et al. ${ }^{38}$ demonstrated a significant increase in $H S D 11 B 2$ transcripts and $11 \beta$-hydroxysteroid dehydrogenase 2 staining in functional ACTH-PAs. This finding was paired with concurrent underexpression of HSDIIB1 and 11ß-hydroxysteroid dehydrogenase 1, which performs the opposite function of converting cortisone to cortisol. Overexpression of $H S D 11 B 2$ and underexpression of $H S D 11 B 1$ were confirmed by Rabbitt et al. ${ }^{69}$ in 2003, and further analysis showed that the inhibition of $11 \beta$ hydroxysteroid dehydrogenase 2 slowed cell proliferation significantly. Although the exact reason remains unknown, Korbonits et al. believed that increased expressions of

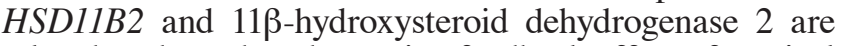
related to the reduced negative-feedback effect of cortisol associated with functional ACTH-PAs. However, little additional research has been done to further elucidate and target this mechanism for the treatment of PAs that cause Cushing's disease.

\section{AKT/Akt, Protein Kinase B}

$A K T$ codes for Akt, or protein kinase $\mathrm{B}$, a serine-threonine kinase that, among other functions, acts as a downstream effector of the phosphoinositide 3-kinase pathway. $A K T$ was originally characterized in 1987 and is a known oncogene. ${ }^{79}$ Akt has 3 isoforms (Akt1, Akt2, and Akt3), all of which have similar functions even though their tissuespecific distributions vary. These functions include anti- apoptosis through indirect modulation of phosphatase and tensin homolog (PTEN)-mediated apoptosis, decreased nuclear factor $\mathrm{\kappa B}$ degradation, increased $\mathrm{p} 53$ regulation, increased cell proliferation by reduced degradation of cyclin D1, and increased cell growth by mammalian target of rapamycin (mTOR) activation..$^{93} \mathrm{Akt} 1$ and $\mathrm{Akt} 2$ are the isoforms most associated with cell proliferation. ${ }^{57}$

In 2005, Musat et al. ${ }^{57}$ showed increased expressions of $A K T 1$ and $A K T 2$ with concurrent overexpressions of the Akt1 and Akt2 proteins in PAs compared with those in the normal pituitary gland. This increased Akt activity has been established further in all types of PAs, including nonfunctional adenomas. Significant research has been performed on this pathway for both pituitary and nonpituitary tumors. Recently, Murasawa et al. ${ }^{56}$ demonstrated that pasireotide decreases the activity of Akt in the AtT-20 mouse corticotrophinoma cell line. Liao et al. ${ }^{44}$ also showed that miR-200c activates Akt and that blocking it can restore PTEN-mediated apoptosis in the MMQ rat prolactinoma cell line. To date, however, no significant advances in the treatment of human functional ACTH-PAs using Akt as a target have been published.

\section{CCND1/Cyclin D1}

The CCNDI gene codes for the cyclin D1 protein, which, along with many other cyclins, functions in the regulation of cyclin-dependent kinases (CDKs). These kinases then go on to activate or inactivate mechanisms most often associated with the cell cycle; for example, cyclin D1 binds to CDK4, which inactivates pRb and allows for movement out of $\mathrm{G}_{1}$ arrest. ${ }^{8}$ Overexpression of cyclin $\mathrm{D} 1$ is known to be present in a large number of neoplasms, both malignant and nonmalignant, and is one of the most common tumorigenic factors. ${ }^{27}$

Despite the widespread nature of cyclin D1 overexpression, however, little published investigation into its role in human PA formation has been definitively shown until recently. In 2011, Hewedi et al. ${ }^{27}$ showed that the expressions of $C C N D 1$ and cyclin D1 were elevated in PAs versus those in the normal pituitary gland. These results were confirmed by Lee et al..$^{42}$ in 2014 using IHC staining. Both Hewedi et al. and Lee et al. associated relative amounts of cyclin D1 overexpression with recurrence. CCND1 and its protein represent new and potentially fruitful avenues of research for all types of PAs.

\section{Underexpressed Genes in ACTH-PAs CDKN1B/p27 Kip1}

The $C D K N 1 B$ gene codes for the $\mathrm{p} 27^{\mathrm{Kipl}}$ protein, which is a member of the Cip/Kip family of CDK inhibitors and is directly involved in regulating CDKs. ${ }^{6,37}$ It is thought that $\mathrm{p} 27^{\mathrm{Kip} 1}$ has a direct regulatory role over CDK4 and that cyclin D1 causes sequestration of $\mathrm{p} 27^{\mathrm{Kipl}}$ in the nucleus, which could be one of the factors that allows for overexpressed cyclin D1 to cause cell-cycle derangement despite the regulatory mechanisms. ${ }^{27}$ It has been shown that $\mathrm{p} 27^{\mathrm{Kip} 1}$ expression inversely correlates with the Ki67-labeling index and that a loss of p27 $7^{\text {Kipl }}$ expression can result in pituitary hyperplasia and tumorigenesis. ${ }^{37}$

Lloyd et al ${ }^{46}$ showed that PAs consistently show oneeighth to one-half the levels of $\mathrm{p} 27^{\mathrm{Kip} 1}$ expression than does 
the normal pituitary gland. This result was confirmed in functional ACTH-PAs and carcinomas by Lidhar et al. ${ }^{45}$ and in multiple PAs by Bamberger et al. ${ }^{6}$ and Komatsubara et al. ${ }^{37}$ more recently, Hewedi et al. ${ }^{27}$ compared cyclin D1 expression with $\mathrm{p} 27^{\mathrm{Kip} 1}$ expression and found an inverse relationship.

Although research into $C D K N 1 B$ and $\mathrm{p} 27^{\mathrm{Kipl}}$ has not been particularly robust, recent publications have pointed to the underexpression of $\mathrm{p} 27^{\mathrm{Kipl}}$ as a potential cause of multiple endocrine neoplasia type $4^{43}$ and as a significant co-mutation for the formation of PAs with multiple endocrine neoplasia type $1 .{ }^{47}$ However, beyond these studies, no significant work exploring the underexpression of $C D K N 1 B$ or $\mathrm{p} 27^{\mathrm{Kip} 1}$ as a potential therapeutic target for the treatment of PAs has been published.

\section{CDKN2A/p16}

CDKN2A is a gene that codes for another CDK inhibitor, p16. Unlike p27 $7^{\mathrm{Kip} 1}$, however, p16 is thought to be more specific to CDK4. As mentioned briefly earlier, the inactivation of CDK4 prevents phosphorylation of $\mathrm{Rb}$, thereby stopping the cell from continuing on in the cell cycle..$^{102}$

In 1996, Woloschak et al. ${ }^{102}$ showed attenuated expression of $C D K N 2 A$ and p16 in multiple types of PAs without any apparent abnormalities in $R b$ expression. Seemann et al. ${ }^{78}$ expanded on this result by showing significant methylation of the $C D K N 2 A$ locus across all PA subtypes and that dysfunction of p16 was associated with increased PA size. It is interesting to note that Tani et al ${ }^{84}$ showed that $C D K N 2 A$ expression was roughly 4 times higher in functional ACTH-PA than in nonfunctioning PAs. They believed that this result explains why functional ACTH-PAs tend to be smaller than other adenoma types.

\section{KISS1/Kisspeptin}

KISSI is a metastasis-suppressor gene that codes for kisspeptin. ${ }^{35}$ Kisspeptins bind to kisspeptin receptors, G protein-coupled receptors that, when activated, prevent chemotaxis and invasion. ${ }^{60}$ These receptors are highly expressed in the pituitary, placenta, pancreas, and spinal cord $^{40}$ and are involved in gonadotropin regulation. ${ }^{34}$

Martínez-Fuentes et al. ${ }^{49}$ showed that the KISSI gene and/or the kisspeptin receptor gene, KISSIR, were significantly underexpressed in PAs relative to those in the normal pituitary gland. They also showed that the administration of kisspeptin 10 to nonfunctioning and growth hormonesecreting PA cells expressing KISS1R induced apoptosis.

Despite clear foundational evidence that KISSI has a significant role in PAs, most studies have been conducted on its role in the hypothalamic-pituitary-gonadal axis rather than as a target for the treatment of PAs. Given that administration of kisspeptin 10 resulted in apoptosis in cultured adenoma cells, it is quite possible that this mechanism could be harnessed in the future to treat PAs.

\section{ACTHR/ACTH-R}

$A C T H R$ is the gene that codes for the ACTH receptor protein ACTH-R, a 7-transmembrane G protein-coupled receptor of the melanocortin receptor family. ${ }^{55}$ It is commonly known that normal pituitary corticotroph cells have a negative-feedback loop with ACTH and cortisol to prevent overproduction.
Morris et al. ${ }^{55}$ demonstrated that ACTHR and ACTH-R are underexpressed in ACTH-secreting PAs. As with $11 \beta-$ hydroxysteroid dehydrogenase 2 overexpression, Morris et al. consider the loss of ACTH-R activity as a potential mechanism for the loss of sensitivity to the normal feedback-inhibition mechanisms that govern ACTH production.

No published research has explored ACTHR or ACTH-R expression as a therapeutic target, despite the fact that restoring the functionality of feedback inhibition could, in theory, significantly lower plasma ACTH levels and thus reduce the severity of Cushing's disease. Morris et al ${ }^{55}$ noted this briefly by demonstrating that functional ACTH-PAs with expressed ACTH-R have lower serum ACTH levels than those that do not. However, no followup on this potential target has been done.

\section{miRNA Expression}

miRNAs are noncoding RNA transcripts that negatively regulate the function of mRNA via binding. ${ }^{52}$ They are difficult to classify alongside the genes and proteins examined earlier, because they are solely gene-expression products without measurable translated protein correlates. Several studies have identified overexpression and underexpression of miRNA transcripts via microarray analysis, often with RT-PCR validation. A list of these studies is included in Table 1, although by microarray analysis there are often hundreds of differences in miRNA expression versus that in the normal pituitary gland, so only the most significant differences are reported here for reference.

It should be noted that Stilling et al. ${ }^{81}$ found that $m i R$ 493 was significantly underexpressed in functional ACTHPAs compared to that in the normal pituitary gland. $m i R$ 493 is a known tumor-suppressor miRNA ${ }^{89}$ Among other targets, $m i R-493$ is thought to regulate the expression of LGALS3, which codes for the galectin 3 protein. ${ }^{81}$ Galectin 3 overexpression is found in ACTH-secreting PAs and is associated with tumor aggressiveness. ${ }^{72,74}$ miRNA-493 and/ or $L G A L S 3 /$ galectin 3 may represent untested, potentially meaningful targets for the treatment of functional ACTHPAs, especially the aggressive or malignant types.

\section{Discussion}

\section{Summary of Key Findings}

Several important genes and proteins were identified by this systematic literature review and included in the subsequent analysis. Of the overexpressed genes identified in functional ACTH-PAs, hPTTGl/securin, NEURODI/ NeuroD1 (Beta2), HSD11B2/11ß-hydroxysteroid dehydrogenase 2, AKT/Akt, protein kinase $\mathrm{B}$, and $C C N D 1 /$ cyclin D1 represent the most well-established candidate genes and collectively form a compelling cross-section of cellular function. Variations in the expressions of these genes and proteins are associated primarily with cell-cycle dysregulation, ACTH overproduction, and reduced cortisol sensitivity. These are all essential elements of what creates the form and function of ACTH-PAs. Figure 2 shows a schematic of the functions of select overexpressed genes and proteins.

Likewise, $C D K N 1 B / \mathrm{p} 27^{\mathrm{Kip} 1}, C D K N 2 A / \mathrm{p} 16, K I S S 1 /$ kisspeptin, $A C T H R / A C T H-R$, and $m i R-493$ represent the same prioritized gene families that were underexpressed 


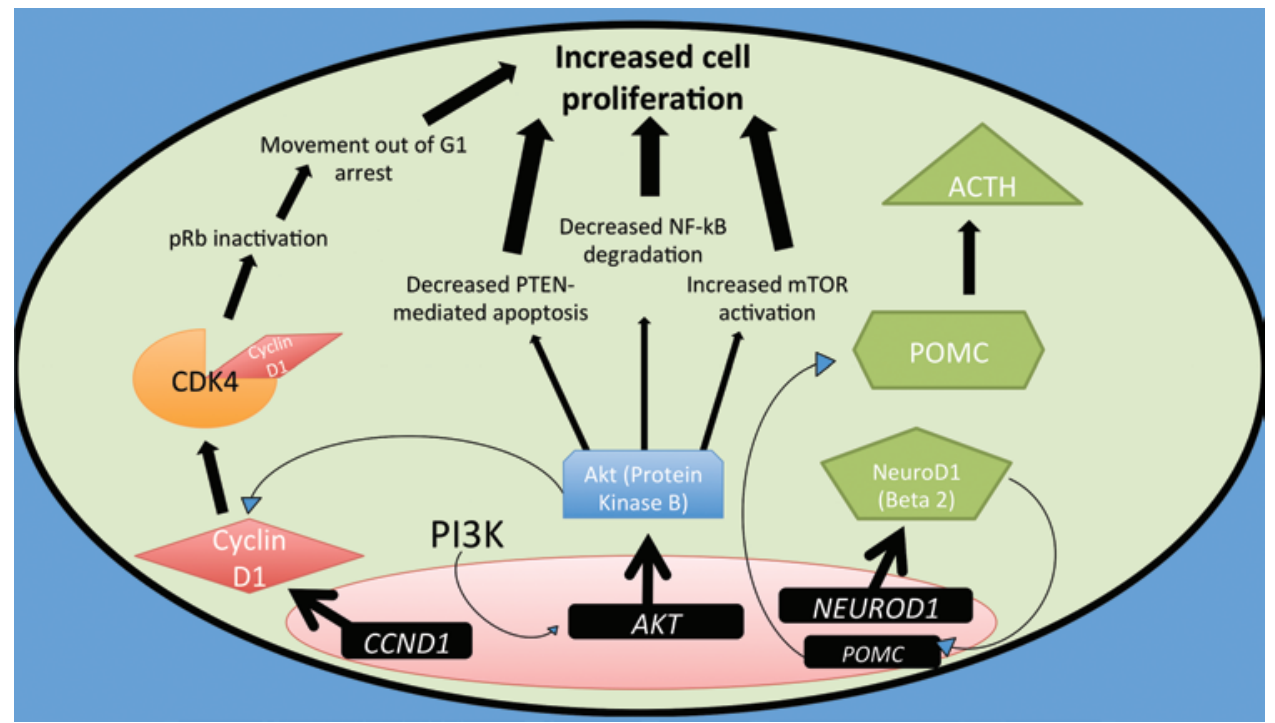

FIG. 2. Schematic diagram demonstrating the downstream effects of certain overexpressed genes and proteins. NF-kB=nuclear factor $\kappa B$; PI3K = phosphoinositide 3-kinase.

in ACTH-PAs. These genes and proteins are involved with cell-cycle regulation, tumor suppression, and cortisolfeedback inhibition. A loss of these elements may facilitate downstream gene expression and protein-level effects with significantly reduced regulation. In total, the significant genes and proteins identified in this review represent potential elements for better understanding the behavior of functional ACTH-PAs and for therapeutic targeting of these signature genes/proteins. Figure 3 shows a schematic of the functions of select underexpressed genes and proteins.

\section{Gene Expression Between Silent and Functional ACTH-PAs}

A thorough discussion of gene expression in functional ACTH-PAs would not be complete without mention of gene-expression differences between silent and functional
ACTH-PAs. Although studies that focused primarily on these differences were not analyzed on the basis of our exclusion criteria, we believe that it is important to briefly highlight key differences. Among these differences, galectin 3 is underexpressed in silent versus functional ACTH-PAs, as demonstrated by Jin et al. ${ }^{33}$ This finding is consistent with the increased expression of galectin 3 as ACTH-PAs increase in aggressiveness. ${ }^{72,74}$ Tateno et al ${ }^{86}$ performed a more in-depth analysis by exploring the expressions of POMC, NEURODI, Tpit, CRHR, $V 1 b R, P C 1 / 3, P C 2, G R_{\text {alpha }}, H S D 11 B 1, H S D 11 B 2, H D A C 2$, $A N X A 1$, and $B R G-1$ (BRM/SWI2-related gene 1) by RTPCR. Expressions of POMC, Tpit, CRHR, VIbR, PC1/3, and $H S D 11 B 2$ were found to be significantly higher in functional ACTH-PAs, and that of NEURODI was found to be higher in silent ACTH-PAs.

As these studies show, there exist significant differenc-

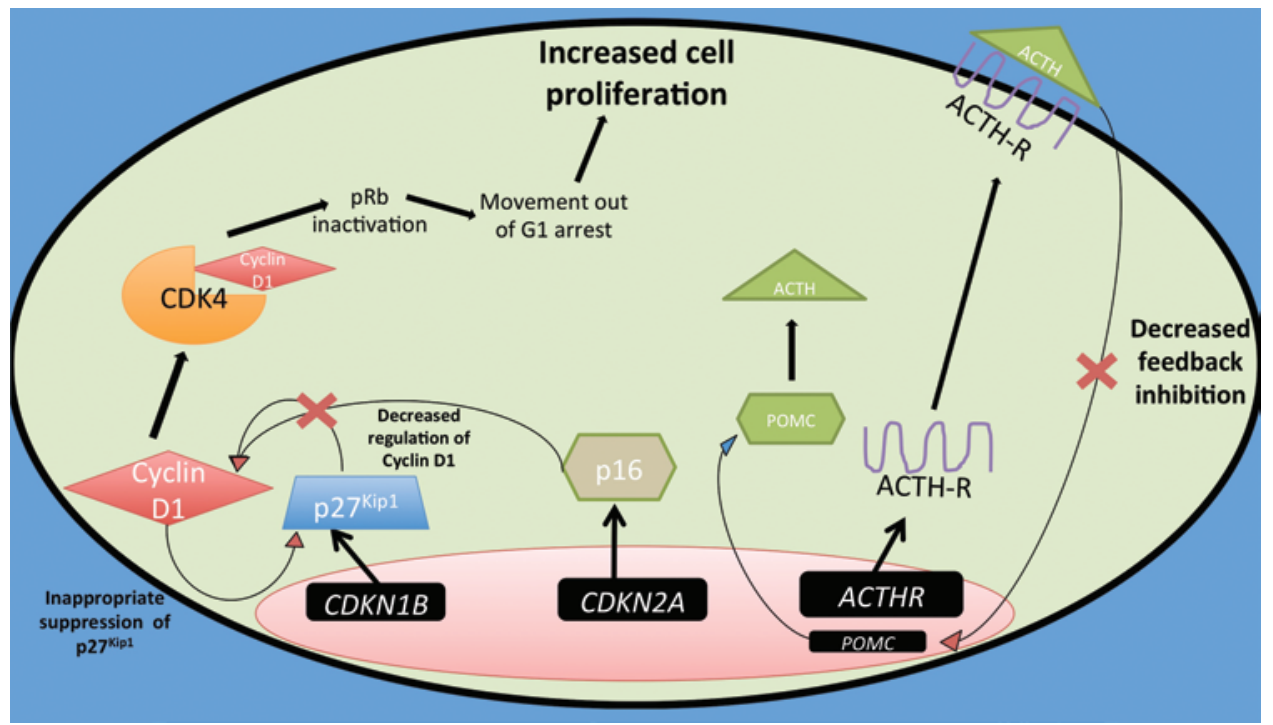

FIG. 3. Schematic diagram demonstrating the downstream effects of certain underexpressed genes and proteins. 
es in gene and protein expressions within the continuum of ACTH-PAs. It is important that we not overlook these differences when treating these tumors and exploring new methods and targets.

\section{Limitations}

Although a strict systematic review methodology was implemented, significant limitations in this type of review exist. One such limitation is the potential disconnect between gene expression and protein expression. Although the process from gene transcription to functional protein is direct in principle, this process can be altered at many points along the way. In other words, the resulting abnormal protein expression does not necessarily imply a similar direction of gene expression and vice versa. Likewise, what is probed for using IHC only implies the presence of a target epitope rather than any guarantee of functionality or even true protein identity. This is less of a problem with Western blot analysis because of the potential size differences between altered and normal proteins. However, the true nature of what we understand as "expression" is not definitive. Our systematic literature review made no distinction between methods of expression analysis and thus was unprotected from this potential pitfall. In recognition of this limitation, Table 1 provides the methods used in each study.

We attempted to minimize this limitation in our analysis by focusing on studies that definitively showed overexpression or underexpression of both the gene and its corresponding protein. However, the genes and proteins presented are not the only important ones generated by this systematic literature review; we believe that they are a strong representation of the major genes known to be involved in functional ACTH-PA formation and behavior.

We also recognize the limitation of screening for functional ACTH-PAs and that, on the basis of our search criteria, it is impossible to distinguish them from silent ACTH-PAs. Because most cases provided aggregated tumor groups classified by IHC staining without further individual information, it is difficult to say with certainty that our analysis reflects only functional ACTH-PAs that cause Cushing's disease. However, significant care was taken by the 2 reviewers to include only functional ACTHPAs, because tumor functionality was one of our inclusion criteria. Because of this care, we believe that the large number of studies performed and included in this analysis provides, on the aggregate, a strong picture of gene and protein expression for functional ACTH-PAs.

\section{Future Avenues of Research}

This systematic literature review brings together the many disparate studies done on functional ACTH-PAs over the past 25 years, and we hope to have highlighted potential treatment targets and fundamental gaps in research and understanding that may hold the key to even greater advances.

PAs, although unique in their function and morphology, have much in common with tumors that arise in other areas of the body. However, unlike many other tumor types, they occur frequently, rarely become carcinomas, and are often surgically excised, which leads to an abundance of specimens for analysis. They represent a key platform for not just the treatment of PAs but also for many other solid tumors. It is hoped that greater attention can be paid in the future to these tumors and that breakthroughs in the treatment of them can translate to other tumor types as well.

\section{Conclusions}

This systematic review of the literature pertaining to gene-expression variations in ACTH-secreting PAs and those in the normal pituitary gland resulted in a series of candidate genes and proteins that may contribute to tumorigenesis, invasion, and hormone production/secretion of ACTH. Many of these important genes and gene products have been discovered and characterized without further exploration of their mechanisms and therapeutic value, and they may represent potential candidate genes for future drug or biomarker development. Many of the genes and proteins highlighted here have shared relevance to the treatment of cancers across the body, lending even more urgency and therapeutic value. Further study of all of these genes and proteins could yield a significant breakthrough in our understanding of not just ACTH-PAs but the spectrum of benign tumorigenesis to carcinogenesis, as well.

\section{References}

1. Alberti VN, Takita LC, de Mesquita MI, Percário S, Maciel RM: Immunohistochemical demonstration of insulin-like growth factor I (IGF-1) in normal and pathological human pituitary glands. Pathol Res Pract 187:541-542, 1991

2. Amaral FC, Torres N, Saggioro F, Neder L, Machado HR, Silva WA Jr, et al: MicroRNAs differentially expressed in ACTH-secreting pituitary tumors. J Clin Endocrinol Metab 94:320-323, 2009

3. Aron DC, Findling JW, Tyrrell JB: Cushing's disease. Endocrinol Metab Clin North Am 16:705-730, 1987

4. Asa SL, Ezzat S: The pathogenesis of pituitary tumors. Annu Rev Pathol 4:97-126, 2009

5. Assimakopoulou M, Zolota V, Chondrogianni C, Gatzounis $\mathrm{G}$, Varakis $\mathrm{J}$ : p75 and TrkC neurotrophin receptors demonstrate a different immunoreactivity profile in comparison to TrkA and TrkB receptors in human normal pituitary gland and adenomas. Neuroendocrinology 88:127-134, 2008

6. Bamberger CM, Fehn M, Bamberger AM, Lüdecke DK, Beil FU, Saeger W, et al: Reduced expression levels of the cellcycle inhibitor p27Kip1 in human pituitary adenomas. Eur J Endocrinol 140:250-255, 1999

7. Barnes L, Eveson JW, Reichart P, David Sidransky (eds): World Health Organization Classification of Tumours: Pathology and Genetics of Head and Neck Tumours. Lyon: IARC Press, 2005

8. Betticher DC: Cyclin D1, another molecule of the year? Ann Oncol 7:223-225, 1996

9. Bottoni A, Zatelli MC, Ferracin M, Tagliati F, Piccin D, Vignali C, et al: Identification of differentially expressed microRNAs by microarray: a possible role for microRNA genes in pituitary adenomas. J Cell Physiol 210:370-377, 2007

10. Buslei R, Kreutzer J, Hofmann B, Schmidt V, Siebzehnrübl F, Hahnen E, et al: Abundant hypermethylation of SOCS-1 in clinically silent pituitary adenomas. Acta Neuropathol 111:264-271, 2006

11. Chile T, Corrêa-Giannella ML, Fortes MA, Bronstein MD, Cunha-Neto MB, Giannella-Neto D, et al: Expression of CRABP1, GRP, and RERG mRNA in clinically non-functioning and functioning pituitary adenomas. J Endocrinol Invest 34:e214-e218, 2011 
12. Cornelius A, Cortet-Rudelli C, Assaker R, Kerdraon O, Gevaert MH, Prévot V, et al: Endothelial expression of endocan is strongly associated with tumor progression in pituitary adenoma. Brain Pathol 22:757-764, 2012

13. Cuevas-Ramos D, Fleseriu M,: Treatment of Cushing's disease: a mechanistic update. J Endocrinol 223:R19-R39, 2014

14. de Keyzer Y, René P, Beldjord C, Lenne F, Bertagna X: Overexpression of vasopressin (V3) and corticotrophinreleasing hormone receptor genes in corticotroph tumours. Clin Endocrinol (Oxf) 49:475-482, 1998

15. Dekkers OM, Biermasz NR, Pereira AM, Roelfsema F, van Aken MO, Voormolen JH, et al: Mortality in patients treated for Cushing's disease is increased, compared with patients treated for nonfunctioning pituitary macroadenoma. J Clin Endocrinol Metab 92:976-981, 2007

16. Dieterich KD, Lehnert H: Decreased expression of corticotropin-releasing factor-binding protein mRNA in ACTH-secreting pituitary adenomas. Exp Clin Endocrinol Diabetes 108:59-62, 2000

17. Elston MS, Gill AJ, Conaglen JV, Clarkson A, Shaw JM, Law AJ, et al: Wnt pathway inhibitors are strongly down-regulated in pituitary tumors. Endocrinology 149:1235-1242, 2008

18. Evans CO, Young AN, Brown MR, Brat DJ, Parks JS, Neish AS, et al: Novel patterns of gene expression in pituitary adenomas identified by complementary deoxyribonucleic acid microarrays and quantitative reverse transcription-polymerase chain reaction. J Clin Endocrinol Metab 86:30973107,2001

19. Ezzat S, Asa SL, Couldwell WT, Barr CE, Dodge WE, Vance ML, et al: The prevalence of pituitary adenomas: a systematic review. Cancer 101:613-619, 2004

20. Feelders RA, Pulgar SJ, Kempel A, Pereira AM: The burden of Cushing's disease: clinical and health-related quality of life aspects. Eur J Endocrinol 167:311-326, 2012

21. Ferretti E, Di Stefano D, Zazzeroni F, Gallo R, Fratticci A, Carfagnini R, et al: Human pituitary tumours express the bHLH transcription factors NeuroD1 and ASH1. J Endocrinol Invest 26:957-965, 2003

22. Filippella M, Galland F, Kujas M, Young J, Faggiano A, Lombardi G, et al: Pituitary tumour transforming gene (PTTG) expression correlates with the proliferative activity and recurrence status of pituitary adenomas: a clinical and immunohistochemical study. Clin Endocrinol (Oxf) 65:536-543, 2006

23. Fleseriu M, Findling JW, Koch CA, Schlaffer SM, Buchfelder $\mathrm{M}$, Gross C: Changes in plasma ACTH levels and corticotroph tumor size in patients with Cushing's disease during long-term treatment with the glucocorticoid receptor antagonist mifepristone. J Clin Endocrinol Metab 99:3718-3727, 2014

24. Fratticci A, Grieco FA, Spilioti C, Giangaspero F, Ventura L, Esposito V, et al: Differential expression of neurogenins and NeuroD1 in human pituitary tumours. J Endocrinol 194:475-484, 2007

25. Giorgi RR, Chile T, Bello AR, Reyes R, Fortes MA, Machado MC, et al: Expression of neurotensin and its receptors in pituitary adenomas. J Neuroendocrinol 20:10521057, 2008

26. Hashimoto K, Koga M, Kouhara H, Arita N, Hayakawa T, Kishimoto T, et al: Expression patterns of messenger ribonucleic acids encoding prohormone convertases (PC2 and PC3) in human pituitary adenomas. Clin Endocrinol (Oxf) 41:185-191, 1994

27. Hewedi IH, Osman WM, El Mahdy MM: Differential expression of cyclin D1 in human pituitary tumors: relation to MIB1 and p27/Kip1 labeling indices. J Egypt Natl Canc Inst 23:171-179, 2011

28. Hossain MG, Iwata T, Mizusawa N, Qian ZR, Shima SW,
Okutsu T, et al: Expression of p18(INK4C) is down-regulated in human pituitary adenomas. Endocr Pathol 20:114-121, 2009

29. Hsu DW, Hooi SC, Hedley-Whyte ET, Strauss RM, Kaplan LM: Coexpression of galanin and adrenocorticotropic hormone in human pituitary and pituitary adenomas. Am J Pathol 138:897-909, 1991

30. Jallepalli PV, Waizenegger IC, Bunz F, Langer S, Speicher MR, Peters JM, et al: Securin is required for chromosomal stability in human cells. Cell 105:445-457, 2001

31. Jiang Z, Gui S, Zhang Y: Analysis of differential gene expression using fiber-optic bead array and pathway analyses in pituitary adenomas. J Clin Neurosci 18:1386-1391, 2011

32. Jiang ZQ, Gui SB, Zhang YZ: Differential gene expression by fiber-optic beadarray and pathway in adrenocorticotrophin-secreting pituitary adenomas. Chin Med J (Engl) 123:3455-3461, 2010

33. Jin L, Riss D, Ruebel K, Kajita S, Scheithauer BW, Horvath E, et al: Galectin-3 expression in functioning and silent ACTH-producing adenomas. Endocr Pathol 16:107-114, 2005

34. Kaiser UB, Kuohung W: KiSS-1 and GPR54 as new players in gonadotropin regulation and puberty. Endocrine 26:277284,2005

35. KiSS-1 metastasis-suppressor [Homo sapiens (human)]. (http://www.ncbi.nlm.nih.gov/gene/3814) [Accessed December 17, 2014]

36. Knosp E, Steiner E, Kitz K, Matula C: Pituitary adenomas with invasion of the cavernous sinus space: a magnetic resonance imaging classification compared with surgical findings. Neurosurgery 33:610-618, 1993

37. Komatsubara K, Tahara S, Umeoka K, Sanno N, Teramoto A, Osamura RY: Immunohistochemical analysis of p27 (Kip1) in human pituitary glands and in various types of pituitary adenomas. Endocr Pathol 12:181-188, 2001

38. Korbonits M, Bujalska I, Shimojo M, Nobes J, Jordan S, Grossman AB, et al: Expression of 11 beta-hydroxysteroid dehydrogenase isoenzymes in the human pituitary: induction of the type 2 enzyme in corticotropinomas and other pituitary tumors. J Clin Endocrinol Metab 86:2728-2733, 2001

39. Korbonits M, Jacobs RA, Aylwin SJ, Burrin JM, Dahia PL, Monson JP, et al: Expression of the growth hormone secretagogue receptor in pituitary adenomas and other neuroendocrine tumors. J Clin Endocrinol Metab 83:3624-3630, 1998

40. Kotani M, Detheux M, Vandenbogaerde A, Communi D, Vanderwinden JM, Le Poul E, et al: The metastasis suppressor gene KiSS-1 encodes kisspeptins, the natural ligands of the orphan $\mathrm{G}$ protein-coupled receptor GPR54. J Biol Chem 276:34631-34636, 2001

41. Lange M, Pagotto U, Hopfner U, Ehrenreich H, Oeckler R, Sinowatz F, et al: Endothelin expression in normal human anterior pituitaries and pituitary adenomas. J Clin Endocrinol Metab 79:1864-1870, 1994

42. Lee EH, Kim KH, Kwon JH, Kim HD, Kim YZ: Results of immunohistochemical staining of cell-cycle regulators: the prediction of recurrence of functioning pituitary adenoma. World Neurosurg 81:563-575, 2014

43. Lee M, Pellegata NS: Multiple endocrine neoplasia syndromes associated with mutation of p27. J Endocrinol Invest 36:781-787, 2013

44. Liao C, Chen W, Fan X, Jiang X, Qiu L, Chen C, et al: MicroRNA-200c inhibits apoptosis in pituitary adenoma cells by targeting the PTEN/Akt signaling pathway. Oncol Res 21:129-136, 2013

45. Lidhar K, Korbonits M, Jordan S, Khalimova Z, Kaltsas $\mathrm{G}, \mathrm{Lu} \mathrm{X}$, et al: Low expression of the cell cycle inhibitor p27Kip1 in normal corticotroph cells, corticotroph tumors, and malignant pituitary tumors. J Clin Endocrinol Metab 84:3823-3830, 1999 
46. Lloyd RV, Jin L, Qian X, Kulig E: Aberrant p27kip1 expression in endocrine and other tumors. Am J Pathol 150:401407, 1997

47. Longuini VC, Lourenço DM Jr, Sekiya T, Meirelles O, Goncalves TD, Coutinho FL, et al: Association between the p27 rs2066827 variant and tumor multiplicity in patients harboring MEN1 germline mutations. Eur J Endocrinol 171:335-342, 2014

48. Malecki MT, Jhala US, Antonellis A, Fields L, Doria A, Orban T, et al: Mutations in NEURODI are associated with the development of type 2 diabetes mellitus. Nat Genet 23:323-328, 1999

49. Martínez-Fuentes AJ, Molina M, Vázquez-Martínez R, Gahete MD, Jiménez-Reina L, Moreno-Fernández J, et al: Expression of functional KISS1 and KISS1R system is altered in human pituitary adenomas: evidence for apoptotic action of kisspeptin-10. Eur J Endocrinol 164:355-362, 2011

50. McCabe CJ, Gittoes NJ, Sheppard MC, Franklyn JA: Increased MEN1 mRNA expression in sporadic pituitary tumours. Clin Endocrinol (Oxf) 50:727-733, 1999

51. McCabe CJ, Khaira JS, Boelaert K, Heaney AP, Tannahill LA, Hussain S, et al: Expression of pituitary tumour transforming gene (PTTG) and fibroblast growth factor-2 (FGF-2) in human pituitary adenomas: relationships to clinical tumour behaviour. Clin Endocrinol (Oxf) 58:141-150, 2003

52. MicroRNA 493 [Homo sapiens (human)]. (http://www.ncbi. nlm.nih.gov/gene/574450) [Accessed December 17, 2014]

53. Minematsu T, Suzuki M, Sanno N, Takekoshi S, Teramoto A, Osamura RY: PTTG overexpression is correlated with angiogenesis in human pituitary adenomas. Endocr Pathol 17:143-153, 2006

54. Moher D, Liberati A, Tetzlaff J, Altman DG: Preferred reporting items for systematic reviews and meta-analyses: the PRISMA statement. Int J Surg 8:336-341, 2010

55. Morris DG, Kola B, Borboli N, Kaltsas GA, Gueorguiev M, McNicol AM, et al: Identification of adrenocorticotropin receptor messenger ribonucleic acid in the human pituitary and its loss of expression in pituitary adenomas. J Clin Endocrinol Metab 88:6080-6087, 2003

56. Murasawa S, Kageyama K, Sugiyama A, Ishigame N, Niioka K, Suda T, et al: Inhibitory effects of SOM230 on adrenocorticotropic hormone production and corticotroph tumor cell proliferation in vitro and in vivo. Mol Cell Endocrinol 394:37-46, 2014

57. Musat M, Korbonits M, Kola B, Borboli N, Hanson MR, Nanzer AM, et al: Enhanced protein kinase B/Akt signalling in pituitary tumours. Endocr Relat Cancer 12:423-433, 2005

58. Nieman LK, Biller BMK, Findling JW, Newell-Price J, Savage MO, Stewart PM, et al: The diagnosis of Cushing's syndrome: an Endocrine Society Clinical Practice Guideline. J Clin Endocrinol Metab 93:1526-1540, 2008

59. Nieman LK, Ilias I: Evaluation and treatment of Cushing's syndrome. Am J Med 118:1340-1346, 2005

60. Ohtaki T, Shintani Y, Honda S, Matsumoto H, Hori A, Kanehashi K, et al: Metastasis suppressor gene KiSS-1 encodes peptide ligand of a G-protein-coupled receptor. Nature 411: 613-617, 2001

61. Oßwald A, Plomer E, Dimopoulou C, Milian M, Blaser R, Ritzel K, et al: Favorable long-term outcomes of bilateral adrenalectomy in Cushing's disease. Eur J Endocrinol 171:209-215, 2014

62. Oyama K, Sanno N, Teramoto A, Osamura RY: Expression of neuro D1 in human normal pituitaries and pituitary adenomas. Mod Pathol 14:892-899, 2001

63. Pei L: Identification of c-myc as a down-stream target for pituitary tumor-transforming gene. J Biol Chem 276:8484-8491, 2001

64. Pei L, Melmed S: Isolation and characterization of a pituitary tumor-transforming gene (PTTG). Mol Endocrinol 11:433441, 1997

65. Poulin G, Turgeon B, Drouin J: NeuroD1/beta2 contributes to cell-specific transcription of the proopiomelanocortin gene. Mol Cell Biol 17:6673-6682, 1997

66. Qian ZR, Asa SL, Siomi H, Siomi MC, Yoshimoto K, Yamada $\mathrm{S}$, et al: Overexpression of HMGA2 relates to reduction of the let-7 and its relationship to clinicopathological features in pituitary adenomas. Mod Pathol 22:431-441, 2009

67. Qian ZR, Sano T, Asa SL, Yamada S, Horiguchi H, Tashiro T, et al: Cytoplasmic expression of fibroblast growth factor receptor-4 in human pituitary adenomas: relation to tumor type, size, proliferation, and invasiveness. J Clin Endocrinol Metab 89:1904-1911, 2004

68. Qian ZR, Sano T, Yoshimoto K, Asa SL, Yamada S, Mizusawa $\mathrm{N}$, et al: Tumor-specific downregulation and methylation of the CDH13 (H-cadherin) and CDH1 (E-cadherin) genes correlate with aggressiveness of human pituitary adenomas. Mod Pathol 20:1269-1277, 2007

69. Rabbitt EH, Ayuk J, Boelaert K, Sheppard MC, Hewison M, Stewart PM, et al: Abnormal expression of 11 beta-hydroxysteroid dehydrogenase type 2 in human pituitary adenomas: a prereceptor determinant of pituitary cell proliferation. Oncogene 22:1663-1667, 2003

70. Raica M, Coculescu M, Cimpean AM, Ribatti D: Endocrine gland derived-VEGF is down-regulated in human pituitary adenoma. Anticancer Res 30:3981-3986, 2010

71. Revill K, Dudley KJ, Clayton RN, McNicol AM, Farrell WE: Loss of neuronatin expression is associated with promoter hypermethylation in pituitary adenoma. Endocr Relat Cancer 16:537-548, 2009

72. Righi A, Morandi L, Leonardi E, Farnedi A, Marucci G, Sisto A, et al: Galectin-3 expression in pituitary adenomas as a marker of aggressive behavior. Hum Pathol 44:2400-2409, 2013

73. Righi A, Zhang S, Jin L, Scheithauer BW, Kovacs K, Kovacs $\mathrm{G}$, et al: Analysis of IMP3 expression in normal and neoplastic human pituitary tissues. Endocr Pathol 21:25-31, 2010

74. Riss D, Jin L, Qian X, Bayliss J, Scheithauer BW, Young WF Jr, et al: Differential expression of galectin-3 in pituitary tumors. Cancer Res 63:2251-2255, 2003

75. Rostomily RC, Bermingham-McDonogh O, Berger MS, Tapscott SJ, Reh TA, Olson JM: Expression of neurogenic basic helix-loop-helix genes in primitive neuroectodermal tumors. Cancer Res 57:3526-3531, 1997

76. Sáez C, Japón MA, Ramos-Morales F, Romero F, Segura DI, Tortolero M, et al: hpttg is over-expressed in pituitary adenomas and other primary epithelial neoplasias. Oncogene 18:5473-5476, 1999

77. Salehi F, Scheithauer BW, Kovacs K, Horvath E, Syro LV, Sharma S, et al: O-6-methylguanine-DNA methyltransferase (MGMT) immunohistochemical expression in pituitary corticotroph adenomas. Neurosurgery 70:491-496, 2012

78. Seemann N, Kuhn D, Wrocklage C, Keyvani K, Hackl W, Buchfelder M, et al: CDKN2A/p16 inactivation is related to pituitary adenoma type and size. J Pathol 193:491-497, 2001

79. Staal SP: Molecular cloning of the akt oncogene and its human homologues AKT1 and AKT2: amplification of AKT1 in a primary human gastric adenocarcinoma. Proc Natl Acad Sci U S A 84:5034-5037, 1987

80. Stefaneanu L, Kovacs K, Horvath E, Lloyd RV: In situ hybridization study of pro-opiomelanocortin (POMC) gene expression in human pituitary corticotrophs and their adenomas. Virchows Arch A Pathol Anat Histopathol 419:107-113, 1991

81. Stilling G, Sun Z, Zhang S, Jin L, Righi A, Kovācs G, et al: MicroRNA expression in ACTH-producing pituitary tumors: up-regulation of microRNA-122 and -493 in pituitary carcinomas. Endocrine 38:67-75, 2010 
82. Tagliati F, Gentilin E, Buratto M, Molè D, degli Uberti EC, Zatelli MC: Magmas, a gene newly identified as overexpressed in human and mouse ACTH-secreting pituitary adenomas, protects pituitary cells from apoptotic stimuli. Endocrinology 151:4635-4642, 2010

83. Tampanaru-Sarmesiu A, Stefaneanu L, Thapar K, Kontogeorgos G, Sumi T, Kovacs K: Transferrin and transferrin receptor in human hypophysis and pituitary adenomas. Am J Pathol 152:413-422, 1998

84. Tani Y, Inoshita N, Sugiyama T, Kato M, Yamada S, Shichiri $\mathrm{M}$, et al: Upregulation of CDKN2A and suppression of cyclin D1 gene expressions in ACTH-secreting pituitary adenomas. Eur J Endocrinol 163:523-529, 2010

85. Tannahill LA, Visser TJ, McCabe CJ, Kachilele S, Boelaert $\mathrm{K}$, Sheppard MC, et al: Dysregulation of iodothyronine deiodinase enzyme expression and function in human pituitary tumours. Clin Endocrinol (Oxf) 56:735-743, 2002

86. Tateno T, Izumiyama H, Doi M, Yoshimoto T, Shichiri M, Inoshita $\mathrm{N}$, et al: Differential gene expression in ACTH -secreting and non-functioning pituitary tumors. Eur J Endocrinol 157:717-724, 2007

87. Theodoropoulou M, Cavallari I, Barzon L, D’Agostino DM, Ferro T, Arzberger T, et al: Differential expression of menin in sporadic pituitary adenomas. Endocr Relat Cancer 11:333344,2004

88. Turner HE, Nagy Z, Sullivan N, Esiri MM, Wass JA: Expression analysis of cyclins in pituitary adenomas and the normal pituitary gland. Clin Endocrinol (Oxf) 53:337-344, 2000

89. Ueno K, Hirata H, Majid S, Yamamura S, Shahryari V, Tabatabai ZL, et al: Tumor suppressor microRNA-493 decreases cell motility and migration ability in human bladder cancer cells by downregulating RhoC and FZD4. Mol Cancer Ther 11:244-253, 2012

90. Umeoka K, Sanno N, Oyama K, Tahara S, Kurotani R, Ikuyama S, et al: Immunohistochemical analysis of RCAS1 in human pituitary adenomas. Mod Pathol 14:1232-1236, 2001

91. Velkeniers B, Vergani P, Trouillas J, D'Haens J, Hooghe RJ, Hooghe-Peters EL: Expression of IL-6 mRNA in normal rat and human pituitaries and in human pituitary adenomas. J Histochem Cytochem 42:67-76, 1994

92. Vidal S, Kovacs K, Bell D, Horvath E, Scheithauer BW, Lloyd RV: Cyclooxygenase-2 expression in human pituitary tumors. Cancer 97:2814-2821, 2003

93. Vivanco I, Sawyers CL: The phosphatidylinositol 3-Kinase AKT pathway in human cancer. Nat Rev Cancer 2:489-501, 2002

94. Wang DG, Johnston CF, Atkinson AB, Heaney AP, Mirakhur M, Buchanan KD: Expression of bcl-2 oncoprotein in pituitary tumours: comparison with c-myc. J Clin Pathol 49:795-797, 1996

95. Wang EL, Qian ZR, Rahman MM, Yoshimoto K, Yamada S, Kudo E, et al: Increased expression of HMGA1 correlates with tumour invasiveness and proliferation in human pituitary adenomas. Histopathology 56:501-509, 2010

96. Wasko R, Jankowska A, Waligorska-Stachura J, Andrusiewicz M, Jaskula M, Sowinski J: Survivin expression in pituitary adenomas. Neuroendocrinol Lett 26:209-212, 2005

97. Weiss R: The myc oncogene in man and birds. Nature 299:910,1982
98. White PC, Mune T, Agarwal AK: 11ß-Hydroxysteroid dehydrogenase and the syndrome of apparent mineralocorticoid excess. Endocr Rev 18:135-156, 1997

99. Wilson RC, Harbison MD, Krozowski ZS, Funder JW, Shackleton CH, Hanauske-Abel HM, et al: Several homozygous mutations in the gene for 11 beta-hydroxysteroid dehydrogenase type 2 in patients with apparent mineralocorticoid excess. J Clin Endocrinol Metab 80:3145-3150, 1995

100. Winczyk K, Pawlikowski M: Immunohistochemical detection of PPARgamma receptors in the human pituitary adenomas: correlation with PCNA. Folia Histochem Cytobiol 43:137-141, 2005

101. Woloschak M, Roberts JL, Post K: c-myc, c-fos, and c-myb gene expression in human pituitary adenomas. J Clin Endocrinol Metab 79:253-257, 1994

102. Woloschak M, Yu A, Xiao J, Post KD: Frequent loss of the P16INK4a gene product in human pituitary tumors. Cancer Res 56:2493-2496, 1996

103. Xu B, Sano T, Yamada S, Li CC, Hirokawa M: Expression of corticotropin-releasing hormone messenger ribonucleic acid in human pituitary corticotroph adenomas associated with proliferative potential. J Clin Endocrinol Metab 85:1220-1225, 2000

104. Yuan Y, Qian ZR, Sano T, Asa SL, Yamada S, Kagawa N, et al: Reduction of GSTP1 expression by DNA methylation correlates with clinicopathological features in pituitary adenomas. Mod Pathol 21:856-865, 2008

105. Zada G, Woodmansee WW, Ramkissoon S, Amadio J, Nose V, Laws ER Jr: Atypical pituitary adenomas: incidence, clinical characteristics, and implications. J Neurosurg 114:336-344, 2011

106. Zafar M, Ezzat S, Ramyar L, Pan N, Smyth HS, Asa SL: Cell-specific expression of estrogen receptor in the human pituitary and its adenomas. J Clin Endocrinol Metab 80:3621-3627, 1995

107. Zhang X, Horwitz GA, Heaney AP, Nakashima M, Prezant TR, Bronstein MD, et al: Pituitary tumor transforming gene (PTTG) expression in pituitary adenomas. J Clin Endocrinol Metab 84:761-767, 1999

108. Zhang X, Horwitz GA, Prezant TR, Valentini A, Nakashima $\mathrm{M}$, Bronstein MD, et al: Structure, expression, and function of human pituitary tumor-transforming gene (PTTG). Mol Endocrinol 13:156-166, 1999

\section{Author Contributions}

Conception and design: Seltzer, Scotton, Carmichael, Zada. Acquisition of data: Seltzer, Scotton, Pangal. Analysis and interpretation of data: Seltzer, Ashton, Pangal. Drafting the article: Seltzer, Scotton, Zada. Critically revising the article: Seltzer, Ashton, Carmichael, Zada. Reviewed submitted version of manuscript: Seltzer, Ashton, Pangal, Carmichael, Zada. Administrative/ technical/material support: Ashton, Scotton. Study supervision: Carmichael, Zada.

\section{Correspondence}

Justin Seltzer, Keck School of Medicine of USC, 1200 N. State St., Ste.3300, Los Angeles, CA 90033.email: jseltzer@usc.edu. 